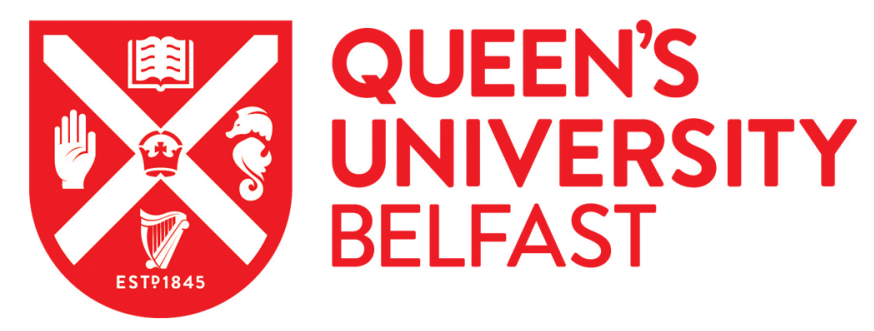

\title{
Voting Behaviour on Free Votes: Simply a Matter of Preferences?
}

Raymond, C. D. (2016). Voting Behaviour on Free Votes: Simply a Matter of Preferences? Parliamentary Affairs. https://doi.org/10.1093/pa/gsw032

Published in:

Parliamentary Affairs

Document Version:

Peer reviewed version

Queen's University Belfast - Research Portal:

Link to publication record in Queen's University Belfast Research Portal

Publisher rights

(c) 2016 The Author

This is a pre-copyedited, author-produced PDF of an article accepted for publication in Parliamentary Affairs following peer review. The version of record [insert complete citation information here] is available online at:

http://pa.oxfordjournals.org/content/early/2016/09/28/pa.gsw032

\section{General rights}

Copyright for the publications made accessible via the Queen's University Belfast Research Portal is retained by the author(s) and / or other copyright owners and it is a condition of accessing these publications that users recognise and abide by the legal requirements associated with these rights.

Take down policy

The Research Portal is Queen's institutional repository that provides access to Queen's research output. Every effort has been made to ensure that content in the Research Portal does not infringe any person's rights, or applicable UK laws. If you discover content in the Research Portal that you believe breaches copyright or violates any law, please contact openaccess@qub.ac.uk. 


\title{
Voting behaviour on free votes: Simply a matter of preferences?
}

\author{
Christopher D. Raymond \\ Lecturer in Politics \\ Queen’s University Belfast
}

\begin{abstract}
Previous research examining the outcomes of free votes concludes that voting behaviour is determined in large part by MPs' personal preferences. However, most studies do not measure preferences directly and ignore other possible determinants of voting behaviour. This piece illustrates the need to address these shortcomings before one concludes that preferences explain the outcomes of free votes. I illustrate this by examining a series of divisions on the issue of House of Lords reform. Using direct measures of preferences and controlling for alternative explanations, the analysis suggests MPs' preferences had little effect on voting behaviour on this issue.
\end{abstract}

\section{Key words}

constituency pressures; free votes; party cohesion; party loyalty; preferences

\section{Acknowledgements}

An earlier draft of this manuscript was presented at the 2016 annual meeting of the Political Studies Association in Brighton. The author would like to thank Pippa Norris for generously sharing the British Representation Study data. Thanks are due also to Thom Oliver who provided helpful comments on an earlier draft of the manuscript. Any errors are the responsibility of the author. 
In studying the voting behaviour of Members of Parliament (MPs), 'party’ plays an influential role in most legislatures, with high levels of cohesion observed on nearly every division. Two explanations for this cohesion are given primacy: while MPs may be kept disciplined by the party whip when their preferences deviate from the rest of their party, party cohesion is also reinforced by the shared preferences of MPs belonging to the same party (Krehbiel, 1993; van Vonno et al., 2014). Because most divisions are whipped, and because party unity is almost universally high, it is difficult to discern the impact of preference-based effects in relation to discipline-based effects.

Many studies examining the impact of preferences on voting behaviour rely on 'free votes' - which are divisions on which the whips are relaxed and MPs are allowed to vote as they wish (Cowley, 1998; Richards, 1970) - in order to control for the effects of party discipline. Though party leaders' decisions to hold free votes (like other roll-call votes) are non-random (Carrubba et al., 2006; Hug, 2010) - e.g. when party leaders fear they will not be able to maintain discipline on bills where the party’s MPs have diverging preferences (Cowley, 1998: 181) - studying free votes provides an opportunity to examine how MPs behave in the absence of the whips. Most previous research examining MPs' voting behaviour on free votes finds that, in the absence of the whips, MPs still tend to coalesce along party lines (Cowley and Stuart, 1997, 2010; Hibbing and Marsh, 1987; Marsh and Read, 1988; Mughan and Scully, 1997; Overby et al., 1998, 2011; Pattie et al., 1994; Plumb, 2013, 2015; Plumb and Marsh, 2011). In line with preference-based explanations, the fact that variables used to measure MPs' personal preferences explain much of the variance in voting behaviour on free votes leads to the conclusion that shared preferences explain the high levels of party cohesion observed on most divisions (both free and whipped), while a lack of party unity can be explained by diverging 
intra-party preferences.

Despite the importance accorded to shared preferences in previous studies of voting behaviour on free votes, there remain reasons for scepticism regarding the effects of preferences. This paper conducts an exploratory study of two potential shortcomings with conclusions regarding preference-based effects on MPs' voting behaviour. One is that most studies lack direct measures of MPs' preferences. Some studies have attempted to operationalise preferences using proxies related to MPs' personal characteristics (e.g., Hibbing and Marsh, 1987; Marsh and Read, 1988; Mughan and Scully, 1997; Overby et al., 1998, 2011; Pattie et al., 1998), which may be problematic because they do not directly measure MPs’ preferences. Others have operationalised preferences using measures derived from MPs’ previous voting behaviour (e.g., Baughman, 2004; Plumb and Marsh, 2011; Plumb, 2015), which may be problematic given that MPs' voting behaviour may not be reflective of their actual preferences (Clinton, 2012). Absent direct measures of preferences, it is difficult to conclude that these variables impact MPs' voting behaviour.

The other is that many studies examining free votes have not accounted for two alternative explanations that may overlap with MPs' preferences. For one, because MPs have reelection related incentives to reflect the preferences of their constituents (André et al., 2014a, 2014b; Cain et al., 1987; Carey and Shugart, 1995) and have been shown to express the interests of their constituents on divisive votes (Baughman, 2004; Overby et al., 2011; Pattie et al., 1994, 1998; Sieberer, 2015), what appear to be personal preference-based effects may instead be due to MPs articulating the preferences of their constituents. Additionally, most previous studies do not account for lingering party effects that are independent of both discipline- and preference-based effects. Drawing from studies showing that party unity remains high even when MPs' 
preferences are not likewise unified (Andeweg and Thomassen, 2011) and when whips are absent (Norton, 2003) - particularly when issues are consequential to parties' agendas (Cowley and Stuart, 1997, 2010; Overby et al., 1998; Plumb and Marsh, 2013) - other research suggests MPs may coalesce due to an underlying sense of loyalty to the party that is independent of the other 'party'-based effects (Raymond and Overby, 2016; Russell, 2014; see also van Vonno et al., 2014). Because these alternative hypotheses may overlap with MPs' preferences, it is important to account for these explanations before one concludes that preferences impact MPs' voting behaviour.

This paper explores these issues by examining a series of divisions in 2003 regarding House of Lords reform that were all decided (in the negative) as free votes. Each measure failed in large part because parties were split - to varying degrees - on these divisions, which previous literature would suggest can be explained by intra-party variance in personal preferences regarding reform (McLean et al., 2003). Examining this particular set of free votes provides an interesting and important chance to observe whether preferences did in fact explain the observed disunity: because free votes allow for intra-party splits in voting behaviour, these divisions allow us to determine the relative effects of preferences versus alternative hypotheses. Additionally, by using survey measures of MPs’ preferences from the British Representation Study (BRS) 2001 (Norris and Lovenduski, 2001), this particular study allows us to measure MPs’ preferences directly, and thus addresses the other noted shortcoming in previous studies. If personal preferences do not explain the disunity in MPs' voting behaviour on these free votes, this would suggest that future analyses of free votes need to pay closer attention to the issues raised here in order to reduce the possibility of reaching spurious conclusions regarding the effects of personal preferences. 
In the next section, I review the issue of House of Lords reform in greater detail in order to provide appropriate context for the analysis. Following that, I discuss the details of my research design before moving to a discussion of the results. A final section concludes with thoughts putting the findings into broader context, as well as a discussion of the implications of this study for future research on the analysis of legislative voting behaviour.

\section{House of Lords reform}

To explore the issues discussed above regarding the appearance of personal preferencebased effects on MPs' voting behaviour, I analyse several divisions regarding House of Lords reform pursued by the Blair government in 2003. ${ }^{1}$ Like other recent attempts, the Blair government's efforts failed to produce any changes in the selection of members of the House of Lords. After the government's White Paper recommending that 20 per cent of the House of Lords be elected faced stiffer-than-anticipated criticism on its release in 2001, and after the Public Administration Select Committee unanimously called for a predominantly elected upper chamber, responsibility for proposing options regarding the shape of House of Lords reform was transferred to a Joint Committee on House of Lords Reform. The Committee presented a range of options for what a reformed upper chamber might look like, of which five were decided in the House of Commons as free votes on 4 February 2003. In the order that they were decided: MPs voted on abolition of the House of Lords, 100 per cent appointed, 100 per cent elected, 80 per cent elected (20 per cent appointed), and 60 per cent elected (40 per cent appointed).

While most research on free votes examines divisions that pass and exhibit high levels of

\footnotetext{
${ }^{1}$ Readers looking for in-depth accounts of attempts at reforming the House of Lords (including this and other episodes) are directed to the excellent reviews and analyses conducted elsewhere (Ballinger, 2014; Kelso, 2009; Raina, 2015; Russell, 2013; on this specific episode, see McLean et al., 2003).
} 
party cohesion, the convention of parties allowing free votes on constitutional matters meant Labour's efforts to reform the House of Lords could not be guaranteed: with significant intraparty splits on these divisions, none of these five proposals passed. Unlike the Liberal Democrats - who were largely (though not perfectly) cohesive in opposing appointment and in supporting all three election-related divisions - Labour and the Conservatives were nearly evenly split on most divisions, (with the exception of the 60 per cent elected measure, where nearly two-thirds of Conservatives voted together against the division). The fact the two largest parties were divided internally on the issue House of Lords reform suggests MPs’ personal preferences played an important role in explaining who voted in favour of reform and who stood in opposition, and in turn why parties demonstrated so little cohesion - as previous research has concluded (McLean et al., 2003). Thus, while this study focuses on one specific attempt to reform the House of Lords (which is but one set of divisions regarding one issue), these particular divisions offer a clear test of the party-as-preference argument.

Even though the intra-party splits observed on these divisions suggest personal preferences led many MPs to deviate from the rest of their parties, those MPs who voted along party lines may have done so due to the partisan nature and consequences these divisions instead of expressing their personal preferences. House of Lords reform was an important partisan issue, as Labour committed in both its 1997 and 2001 manifestos to reforming selection to the House of Lords. Though Labour party unity was weaker on these divisions than in previous research, some MPs may still have recognised the partisan implications of these divisions and, thus, may have been motivated to vote according to a sense of loyalty to the party instead of their personal preferences - similar to the behaviour of MPs seen in previous research on free votes with partisan consequences (Cowley and Stuart, 1997, 2010; Plumb and Marsh, 2013). On this 
occasion, Labour MPs’ expressed their party loyalties by supporting the party’s leader: despite the fact that many of the most vocal supporters of electoral reform for the House of Lords came from Labour's ranks, a sizeable number voted in favour of an all-appointed House of Lords following the Prime Minister's expressed support for this option (and against options creating a hybrid House of - appointed and elected - Lords). Though this was a free vote, meaning that Labour MPs were free to express their preferences for an elected House of Lords, ${ }^{2}$ there is some evidence many voted (against their own preferences) in favour of an all-appointed House of Lords in an effort to 'support Tony' and protect the party from the embarrassment of defeating its leader (McLean et al., 2003, pp. 308-309). To ensure the position of the party’s leader in favour of an all-appointed Lords was not defeated on the three motions seeking to elect all/some of the House of Lords, which in turn would embarrass the party further (after having already backtracked on its manifesto commitment to reform), Labour MPs may have demonstrated continued loyalty to the party’s leader by opposing these three divisions. Instead of voting according to their own preferences for reform, this suggests many MPs voted in their party’s (and leader’s) interests.

Before one can conclude that MPs’ personal preferences explained the outcome, one must also consider the possibility constituency pressures influenced MPs' behaviour on these divisions. Given MPs’ need to develop and maintain personal votes that help increase their chances of re-election (e.g., André et al., 2014a, 2014b; Cain et al., 1987), we would expect MPs to vote to represent their constituents’ preferences. Because House of Lords reform became embroiled in larger partisan conflicts, support for reforming the House of Lords may have

\footnotetext{
${ }^{2}$ Though the whips - especially Labour - were active on these divisions (though not all working in the same direction: Kelso, 2009, pp.173), MPs appear to have been genuinely free to vote as they wished. For instance, deviating from the Prime Minister's stated position did not negatively affect the careers of MPs like Yvette Cooper or David Miliband, who went on to become cabinet ministers after voting against Tony Blair's stated position in favour of a fully appointed House of Lords.
} 
divided along similar lines among constituents as well. For instance, replacing the House of Lords with an elected second chamber has long been a party issue for Liberal Democrats (dating back to the Liberals' policy from the nineteenth century). Survey evidence consistently suggests Liberal Democrats overwhelmingly support an elected House of Lords (Henry, 2012; Ipsos MORI, 2014; Russell, 2013). Because of this, MPs from constituencies with more Liberal Democrat constituents - regardless of their personal preferences or party's position - may have been more likely to vote against retaining a fully appointed chamber, and instead more likely to vote in favour of the motions to elect members of the upper chamber. Though the pressure to represent Liberal Democrat voters' desires for an elected House of Lords would have been felt the most by Liberal Democrat MPs (due to the fact they represent more Liberal Democrat voters than other MPs), Labour and Conservative MPs with large numbers of Liberal Democrat constituents may have supported an elected House of Lords due to the prospects of developing personal votes that could help them win re-election.

In a similar vein, MPs may have felt pressures from Conservative constituents to oppose reform. Under William Hague’s leadership, the party made opposing the government's reform efforts a party issue. Though the party would adopt the position of Iain Duncan Smith - leader at the time the free votes were cast in 2003 - in favour of an 80 per cent-elected House of Lords to try to outflank Labour after the Blair government began to walk back its promises for an elected second chamber (Cowley and Stuart, 2004, pp. 357-358), the party’s members and voters have long been sceptical of reforming the House of Lords: Conservative voters have been consistently and significantly less likely to support election (Henry, 2012; Ipsos MORI, 2014), less favourable of ending life peerages (Russell, 2013, pp. 244-245), and more likely to oppose reform in general (Henry, 2012). Though doubtfully one of the most important issues to voters, 
the fact public opinion divided largely along party lines prior to the votes on House of Lords reform suggests some voters cared enough about the issue for the parties to divide along similar lines and become invested in its outcome. ${ }^{3}$ Because many Conservatives opposed all efforts to reform the House of Lords (or at best were lukewarm to pursuing reform), Conservative MPs from constituencies with larger Conservative Party support may have opposed all reform efforts in order to placate this constituency within the party for fear of deselection by their constituency associations. Similarly, most other MPs from constituencies with large numbers of Conservative supporters had incentives to cultivate personal votes by opposing House of Lords reform.

Although Conservative constituents put pressure on MPs to oppose House of Lords reform, there is reason to believe Labour MPs from constituencies with more Conservative Party supporters were more likely to support an elected House of Lords. Because most Labour voters supported some type of reform (e.g. Russell, 2013), Labour MPs from constituencies with more Conservative Party supporters would have felt greater pressure to support an elected House of Lords. While Labour MPs from constituencies more secure from Conservative challengers were free to express their party loyalties by voting for Blair’s stated positions, Labour MPs from constituencies facing stronger challengers may have been more likely to vote in line with their constituents' preferences in order to minimise the damage done to the party’s reputation - and thus their personal chances of re-election - among Labour voters who were promised an elected House of Lords in the party’s 1997 and 2001 manifestos.

\footnotetext{
${ }^{3}$ Data from the 1997 British Election Study show that while 63 and 61 per cent of Labour and Liberal Democrat voters, respectively, felt that change to the House of Lords was needed, 55 per cent of Conservatives stated that the House of Lords should remain unchanged. Additionally, while Conservative supporters in the British Social Attitudes Survey in 2002 were somewhat supportive of House of Lords reform, they remained decidedly less supportive of the proposed reforms than Labour and Liberal Democrat supporters. Compared with 34 and 41 per cent of Labour and Liberal Democrat supporters, 53 per cent of Conservative supporters preferred either an equal balance of elected and appointed members or appointing 100 per cent of the House of Lords. The fact Conservative supporters were less enthusiastic for reform suggests they may have been willing to reward politicians who opposed reforms that went too far in their eyes.
} 
Thus, there is need to examine MPs' voting behaviour on this issue in order to confirm that preferences really did play the role ascribed to them in previous research. In addition to concerns regarding the direct measurement of preferences, there is also reason to believe that constituency pressures and party loyalty also affected MPs' behaviour. While there is reason to believe that, similar to other cases examined in previous research, preferences played a definitive role in explaining MPs' behaviour on the issue of House of Lords reform, this must be demonstrated using direct measures of preferences and that such effects are robust to the relative effects of constituency pressures and party loyalty.

\section{Research design}

To estimate the impact of personal preferences on MPs’ voting behaviour, I analyse (separately) support for four divisions regarding House of Lords reform: 100 per cent appointed, 100 per cent elected, 80 per cent elected, and 60 per cent elected. ${ }^{4}$ Those voting in favour of the motion are coded one, while those voting against are coded zero. Because the dependent variables are binary, I use logistic regression to estimate support for each motion. ${ }^{5}$

These divisions are ideal for analysing the impact of personal preferences on voting behaviour because data are available to measure the personal preferences of MPs directly. Specifically, I use data taken from the British Representation Study 2001 (Norris and Lovenduski, 2001), which surveyed candidates' attitudes regarding two key attitudes which may

\footnotetext{
${ }^{4}$ I exclude the amendment to abolish the House of Lords. This is because the measure of MPs' preferences used here regards MPs' preferences for an elected House of Lords, but says nothing about MPs' preferences for abolishment. Thus, the data used here do not provide a direct test of the impact of preferences on support for this particular division.

${ }^{5}$ Recognising the possibility that MPs who did not vote on every measure may have abstained tactically to avoid hurting their prospects of re-election, I also used multinomial logistic regression models to estimate support/opposition/absence as a robustness test. While the results show that all but one of the significant effects in the models using the binary measure of the dependent variable remain significant, the measure of MPs' preferences for an elected House of Lords fails to reach significance.
} 
have been relevant to deciding House of Lords reform. Of 999 candidates surveyed prior to the 2001 election, 296 were elected MPs. As seen in Table 1, the BRS produces samples on each division that are broadly representative both of the final outcomes and of the party-specific vote shares for the three largest parties. ${ }^{6}$

\section{Table 1 about here}

One of those variables collected by the BRS regards MPs' attitudes towards the efforts to reform the House of Lords. Specifically, I include a measure of MPs' attitudes towards the election of members of the House of Lords. Using a five-point scale ranging from 'definitely should' to 'definitely should not', candidates interviewed by the BRS responded to the following statement: 'Replace the House of Lords with an elected Second Chamber'. Responses were recoded ranging from zero ('definitely should not') to four ('definitely should'). ${ }^{7}$

In addition to MPs' preferences for an elected House of Lords, I also examine the impact of several control variables. In addition to MPs' attitudes towards an elected House of Lords, voting behaviour may have differed between MPs elected for the first time in the 2001 election and incumbent MPs who have been socialised to prefer the House of Lords' status quo during their time in Parliament. To test this possibility, I include a variable coded one for MPs elected for the first time in the 2001 general election and zero for MPs elected prior to 2001.

To control for the possibility that MPs' voting behaviour is affected by lingering party

\footnotetext{
${ }^{6}$ The BRS sample is also representative of the full membership of the House of Commons in terms of the Conservative and Liberal Democrat vote share variables, as well as MPs' ages and gender. While non-Labour and non-incumbent MPs are slightly underrepresented, these differences are not substantial (differences of 7 and 4 percentage points, respectively).

${ }^{7}$ The frequencies falling into each category are as follows: 49 (0 - 'definitely should not'), 24 (1), 6 (2), 47 (3), 165 (4 - 'definitely should'). Because the majority of MPs stated that they (strongly) agreed with an elected upper chamber, I also estimated models substituting this ordinal measure with a dummy variable coded one for MPs who strongly agreed with an elected upper chamber and zero otherwise; I also estimated models substituting this variable with one coded one for all MPs who agreed or strongly agreed for an elected chamber coded one, and zero otherwise. The results using these alternative measures are substantively equivalent to those using the ordinal measure.
} 
loyalty-based effects, I include a variable coded one for Labour MPs, and zero otherwise. ${ }^{8}$ The discussion above suggests we should see loyalty effects leading Labour MPs to support continued appointment and oppose an elected House of Lords. To account for the impact of constituency pressures, I include two variables: one variable measuring the percentage of the constituency-level vote won by the Liberal Democrats in 2001, and another measuring the constituency-level vote share won by the Conservatives. While the discussion above suggests higher Liberal Democrat vote shares should put pressure on MPs to oppose appointment and support electing the House of Lords, higher Conservative vote shares should put pressure on MPs to support appointment and oppose electing the House of Lords. To account for the possibility that the relationship between Conservative vote shares and support for reform is reversed among Labour MPs - with Labour MPs from constituencies with larger Conservative vote shares looking to minimise the damage Labour's reversal of policy had on their personal chances of re-election by voting in line with Labour voters' preferences - I created an interaction between the Conservative vote share variable and the variable measuring Labour MPs. ${ }^{9}$

\section{Results}

Table 2 presents parameter estimates both for the models with controls and for bivariate models including preferences for an elected House of Lords only. Though first-term MPs were significantly more likely to support the three motions proposing to elect most or all members of

\footnotetext{
${ }^{8}$ While it would have been interesting to explore the effects of lingering party loyalties among Conservative and Liberal Democrat voters, the smaller number of observations among these two parties inhibited me from doing so.

${ }^{9}$ I also estimated models including an interaction between Labour MPs and Liberal Democrat vote shares to account for the possibility that pressures from Liberal Democrat constituents were felt particularly by Labour MPs, whose own supporters also sought an elected House of Lords. Models including this interaction did not significantly improve model fit, thereby suggesting the impact of Liberal Democrat vote shares was not significantly different among Labour MPs.
} 
the Lords, none of the coefficients for the variable measuring MPs' preferences for an elected

House of Lords - in either the bivariate or multivariate models - reaches statistical

significance. ${ }^{10}$ Despite the emphasis in previous research on the importance of MPs' personal

preferences in deciding how to vote on free votes, these results suggest personal preferences

were not determinative of MPs' voting behaviour on these divisions. ${ }^{11}$

Table 2 about here

Instead, these findings suggest that voting behaviour was determined more by

constituency pressures and lingering party loyalties than by personal preferences. Although the

relatively low percentages of observations correctly predicted by each model suggest limits to

the power of these explanations in this instance, the fact remains that the results suggest

constituency pressures and party loyalties had stronger effects on voting behaviour than

preferences for an elected House of Lords. In order to display the estimated effects of

constituency pressures more easily - given the conditional nature of the hypothesised effects -

Figure 1 presents predicted probabilities displaying the impact of the Liberal Democrat vote

\footnotetext{
${ }^{10}$ One concern with examining the impact of MPs' preferences for an elected House of Lords on their voting behaviour is that some evidence provided by McLean et al. (2003) suggests MPs voted tactically. Specifically, the concern is that MPs who preferred an elected House of Lords may not have supported the motions proposing to elect 80 or 60 per cent of the Lords, which might result in type-II errors when estimating the effect of preferences for an elected House of Lords on these two motions (but not when analysing the motions proposing to appoint or elect 100 per cent of the Lords, as these motions represent the two logical extremes - for/against an elected House of Lords). To address these concerns, I re-estimated each model after omitting respondents who voted for an all-elected House of Lords but not in favour of the 80 or 60 per cent elected motions in order to remove those potentially voting strategically from the sample. Because the results of these models confirmed the findings presented here, I conclude that the weak effects of personal preferences seen here are not due to strategic voting.

${ }^{11}$ One caveat to this conclusion is in order. Although this study employed direct measures of MPs' personal preferences, the research design applied here cannot rule out the possibility that the reason for the weak effects of preferences was due to changes in MPs' preferences after hearing the arguments made for/against reform in the debates. However, because most models of voting behaviour assume MPs hold fixed preferences, finding that MPs' preferences shift during debates would weaken the conclusion MPs' preferences impact their voting behaviour. Instead, this would suggest the effects of MPs' preferences are more endogenous than exogenous (perhaps endogenous to party loyalties or constituency pressures if MPs were persuaded by positions taken by other MPs from their parties or by the concerns raised by their constituents), and thus less important for explaining voting behaviour than previous research has concluded.
} 
share variable on voting behaviour between Labour and non-Labour MPs, while Figure 2 presents the predicted probabilities associated with the Conservative vote share variable between Labour and non-Labour MPs. To account for differences in these variables' estimated effects between Labour and all other MPs, I present predicted probabilities calculated for both sets of MPs holding all other variables at their median values.

Figures 1 and 2 about here

Regarding the impact of Liberal Democrat vote shares on MPs’ voting behaviour, the results in Figure 1 suggest that variation in Liberal Democrat vote shares influenced MPs’ voting behaviour on each motion. Though the predicted probabilities of supporting the three electionrelated motions are slightly lower among Labour MPs (and slightly higher on the all-appointed measure) than among other MPs, higher Liberal Democrat vote shares are associated with increased support for the three election-focused motions (and decreased support for the allappointed motion) for both Labour and other MPs. These estimated effects were statistically significant at the 0.10 level or better, as indicated by the coefficients for the Liberal Democrat vote share variable in each model in Table 2. In keeping with the literature suggesting MPs will vote to reflect constituency preferences on free vote divisions as a means to increase their chances of re-election (Baughman, 2004; Overby et al., 2011; Pattie et al., 1994, 1998), these results show that MPs in constituencies where the Liberal Democrats fared well in the 2001 elections were more likely to vote in favour of electing members of the House of Lords (and less likely to vote for appointment) than those MPs in constituencies where the Liberal Democrats fared worse.

The results in Figure 2 suggest the impact of constituency pressures coming from Conservative voters was conditional on the party of the MP. Among non-Labour MPs, the results 
in Figure 2 suggest higher Conservative vote shares put pressure on MPs to support appointment and oppose efforts to elect the House of Lords: higher Conservative vote shares were associated with higher probabilities of support for an all-appointed House of Lords, while higher Conservative vote shares were associated with lower probabilities of supporting an elected House of Lords (though the coefficients for the partial effects of Conservative vote shares are significant only in the models predicting support for the 80 and 60 per cent measures, and then only at the 0.10 level). Consistent with the argument that Labour MPs facing greater threats from Conservative challengers responded by supporting an elected House of Lords in order to represent Labour voters' preferences (rather than voting against an elected House of Lords out of party loyalty), the results in Figure 2 show that higher Conservative vote shares among Labour MPs were associated with higher probabilities of supporting the election of members of the House of Lords. The probability that Labour MPs would support the three election-related motions increases as the share of the vote won by the Conservatives increases, while the probability that Labour MPs would support the 100 per cent appointment motion decreases as the Conservative Party vote share increases.

In order to see the estimated effects of lingering Labour Party loyalties on voting behaviour, Figure 3 presents the predicted changes in probabilities associated with Labour Party affiliation (relative to all other MPs) on each division. Because the estimated effect of Labour Party affiliation is conditional on the Conservative Party vote share variable, I present the estimated changes in probabilities for Labour MPs in constituencies at the Labour-specific lower and upper quartiles of the Conservative vote share variable. The results show that Labour affiliation leads to significant increases in support for appointment at both low and high levels of Conservative Party vote shares. This suggests Labour Party loyalty helped bring many in the 
party to support the position taken by the Prime Minister against their own personal preferences for an elected second chamber. On the three motions calling for the election of members of the House of Lords, Labour MPs are significantly less likely to support each motion at lower levels of Conservative support, with this effect weakening at higher levels of Conservative support. This suggests that loyalty to the party led Labour MPs in constituencies that were electorally secure from Conservative challengers to support the Prime Minister's position on appointment at lower levels of Conservative support. However, many Labour MPs in constituencies with higher levels of Conservative support feeling less secure about their prospects of re-election felt pressures to represent the preferences of their Labour constituents by supporting an elected House of Lords, and thus were much more likely to break with those Labour MPs supporting the Prime Minister’s position.

Figure 3 about here

\section{Conclusion}

While a growing body of research examining free votes concludes that party cohesion remains high due to shared preferences, this paper has explored two issues which suggest greater caution is needed in interpreting the reasons for unity/disunity on free votes. Specifically, this paper has examined the importance of the direct measurement of preferences and accounting for alternative explanations overlapping with personal preferences. Examining four free vote divisions regarding House of Lords reform in 2003, this paper analysed whether MPs' voting behaviour on these divisions was determined by their personal preferences.

Contrary to most research on free votes, the results suggested personal preferences were only weakly associated with voting behaviour regarding House of Lords reform. The analysis 
above provided a clear test of the party-as-preference argument: because these free votes allowed MPs to express their personal preferences independently of the party whips, the fact MPs' personal preferences did not affect their voting behaviour is an important finding, suggesting the impact of personal preferences was overstated in this instance (and possibly in other cases as well). Instead of personal preferences, the results presented here suggest that MPs voted in favour of/against efforts to reform the House of Lords due more to constituency pressures and party loyalties that are independent of both the whip and shared preferences.

Certainly, one cannot draw wide-ranging conclusions regarding the impact of preferences - especially on whipped divisions - based on the results of four free votes dealing with one issue. Because these four divisions are doubtfully reflective of MPs' behaviour on most divisions, these findings do not undermine the importance of personal preferences accorded by previous research for understanding party cohesion in legislative voting behaviour. However, they do suggest greater caution is needed in future research examining the results of free votes before concluding that MPs' preferences impacted the results. Although this piece is only exploratory in scope and focused on one particular case, this finding suggests future research needs to determine when and under what conditions personal preferences play a significant role in shaping MPs' voting behaviour, and when they do not. At the very least, these results suggest more careful attention should be given to determining the precise impact of personal preferences, particularly regarding the measurement of preferences. Additionally, given the impact of constituency pressures and party loyalties seen here and in previous research, future research should give greater attention to the tensions between personal preferences on the one hand and the preferences of MPs' constituents and MPs' party loyalties on the other. If preferences play a weaker role than constituency pressures and party loyalties on other issues, then previous research may have 
ignored important explanations and over-estimated the degree to which MPs' voting behaviour is shaped by personal preferences.

\section{References}

Andeweg, R.B. and Thomassen, J. (2011) 'Pathways to party unity: Sanctions, loyalty, homogeneity and division of labour in the Dutch parliament’, Party Politics, 17, 655-672.

André, A., Freire, A., and Papp, Z. (2014) 'Electoral Rules and Legislators’ Personal VoteSeeking' In Deschouwer, K. and Depauw, S. (eds.), Representing the People: A Survey Among Members of Statewide and Substate Parliaments, Oxford: Oxford University Press pp. 87-109.

André, A., Gallagher, M., and Sandri, G. (2014) ‘Legislators’ Constituency Orientation’ In Deschouwer, K. and Depauw, S. (eds.), Representing the People: A Survey Among Members of Statewide and Substate Parliaments, Oxford: Oxford University Press pp. 166-187.

Ballinger, C. (2014) The House of Lords, 1911-2011: A century of non-reform. Oxford: Hart.

Baughman, J. (2004) 'Party, constituency, and representation: Votes on abortion in the British House of Commons', Public Choice, 120, 63-85.

Cain, B.E., Ferejohn, J., and Fiorina, M. (1987) The Personal Vote: Constituency Service and Electoral Independence. Cambridge: Harvard University Press.

Carey, J.M., and Shugart, M.S. (1995) 'Incentives to cultivate a personal vote: A rank ordering of electoral formulas', Electoral Studies, 14, 417-439.

Carrubba, C.J., Gabel, M., Murrah, L., Clough, R., Montgomery, E. and Schambach, R. (2006) 'Off the record: Unrecorded legislative votes, selection bias and roll-call vote 
analysis’, British Journal of Political Science, 36, 691-704.

Clinton, J.D. (2012) 'Using Roll Call Estimates to Test Models of Politics’, Annual Review of Political Science, 15, 79-99.

Cowley, P. (ed.) (1998) Conscience and Parliament. London: Frank Cass.

Cowley, P. and Stuart, M. (1997) ‘Sodomy, Slaughter, Sunday Shopping and Seatbelts Free Votes in the House of Commons, 1979 to 1996', Party Politics, 3, 119-130.

Cowley, P. and Stuart, M. (2004) 'Still causing trouble: The Conservative parliamentary party', The Political Quarterly, 75, 356-361

Cowley, P. and Stuart, M. (2010) 'Party Rules, OK: Voting in the House of Commons on the Human Fertilisation and Embryology Bill’, Parliamentary Affairs, 63, 173-181.

Heath, A., Jowell, R. and Curtice, J. (1999) British General Election Study, 1997, 2nd Edition. Colchester, Essex: UK Data Archive, available at: http://www.britishelectionstudy.com/data-objects/cross-sectional-data/ (Accessed 13 September 2015).

Henry, J. (2012) ‘House of Lords - reform or retain?’, available at: https://yougov.co.uk/news/2012/05/10/house-lords-reform-your-views/ (Accessed: 31 January 2016).

Hug, S. (2010) 'Selection Effects in Roll Call Votes’, British Journal of Political Science, 40, 225-235.

Hibbing, J.R. and Marsh, D. (1987) 'Accounting for the Voting Patterns of British MPs on Free Votes’, Legislative Studies Quarterly, 12, 275-297.

Ipsos MORI. (2014) 'State of the Nation: Survey for Joseph Rowntree Reform Trust’, available at: https://www.ipsos-mori.com/researchpublications/researcharchive/3446/State-of-the- 
Nation.aspx (Accessed 31 January 2016).

Kelso, A. (2009) Parliamentary Reform at Westminster. Manchester: Manchester University Press.

Krehbiel, K. (1993) 'Where’s the Party?’, British Journal of Political Science, 23, 235-266.

Marsh, D. and Read, M. (1988) Private Members' Bills. New York: Cambridge University Press.

McLean, I., Spirling, A., and Russell, M. (2003) 'None of the Above: The UK House of Commons Votes on Reforming the House of Lords, February 2003’, Political Quarterly, 74, 298-310.

Mughan, A. and Scully, R.M. (1997) 'Accounting for Change in Free Vote Outcomes in the House of Commons', British Journal of Political Science, 27, 640-647.

National Centre for Social Research. (2004) British Social Attitudes Survey, 2002. UK Data Service (SN: 4838), available at: http://dx.doi.org/10.5255/UKDA-SN-4838-1 (Accessed 28 July 2016).

Norris, P. and Lovenduski, J. (2001) The British Representation Study 2001, available at: www.pippanorris.com (Accessed 16 October 2012).

Norton, P. (2003) 'Cohesion without discipline: Party voting in the House of Lords’, Journal of Legislative Studies, 9, 57-72.

Overby, L.M., Tatalovich, R. and Studlar, D.T. (1998) 'Party and Free Votes in Canada Abortion in the House of Commons', Party Politics, 4, 381-392.

Overby, L.M., Raymond, C., and Taydas, Z. (2011) 'Free Votes, MPs, and Constituents: The Case of Same-Sex Marriage in Canada’, American Review of Canadian Studies, 41, 465478.

Plumb, A. (2013) 'Research Note: A Comparison of Free Vote Patterns in Westminster-Style 
Parliaments’, Commonwealth \& Comparative Politics, 51, 254-266.

Plumb, A. (2015) 'How Do MPs in Westminster Democracies Vote When Unconstrained by Party Discipline? A Comparison of Free Vote Patterns on Marriage Equality Legislation’, Parliamentary Affairs, 68, 533-554.

Plumb, A. and Marsh, D. (2013) ‘Beyond party discipline: UK Parliamentary voting on fox hunting', British Politics, 8, 313-332.

Raina, P. (2015) House of Lords Reform: A History 1971-2014: The Exclusion of Hereditary Peers, Volume 4. Frankfurt am Main: Peter Lang Edition.

Raymond, C.D. and Overby, L.M. (2016) ‘What’s in a (Party) name? Examining preferences, discipline, and social identity in a parliamentary free vote', Party Politics, 22, 313-324.

Richards, P.G. (1970) Parliament and Conscience. London: George Allen and Unwin.

Russell, M. (2013) The contemporary House of Lords: Westminster bicameralism revived. Oxford: Oxford University Press.

Russell, M. (2014) ‘Parliamentary party cohesion: Some explanations from psychology’, Party Politics, 20, 712-723.

Sieberer, U. (2015) 'Using MP statements to explain voting behaviour in the German Bundestag: An individual level test of the Competing Principals Theory', Party Politics, 21, 284-294. van Vonno, C.M.C., Malka, R.I., Depauw, S., Hazan, R.Y. and Andeweg, R.B. (2014) ‘Agreement, Loyalty, and Discipline’ In Deschouwer, K. and Depauw, S. (eds.), Representing the People: A Survey Among Members of Statewide and Substate Parliaments, Oxford: Oxford University Press pp. 110-136. 
Table 1 Results of Four Free Vote Divisions Regarding House of Lords Reform in 2003

\begin{tabular}{lllll}
\hline \multirow{2}{*}{ Party } & \multicolumn{4}{c}{ Division } \\
\cline { 2 - 5 } Labour & Appointment & $100 \%$ Elected & $80 \%$ Elected & $60 \%$ Elected \\
\cline { 2 - 5 } Conservative & $(49.0 \%$ & $44.5 \%$ & $43.8 \%$ & $43.6 \%$ \\
& $40.8 \%$ & $42.5 \%$ & $49.0 \%$ & $33.8 \%$ \\
Lib Dem & $(42.6 \% / 61)$ & $(44.8 \% / 58)$ & $(50.0 \% / 64)$ & $(37.5 \% / 64)$ \\
& $6.1 \%$ & $85.1 \%$ & $93.9 \%$ & $87.5 \%$ \\
Other & $(0 \% / 16)$ & $(86.7 \% / 15)$ & $(100 \% / 16)$ & $(93.8 \% / 16)$ \\
& $47.4 \%$ & $71.4 \%$ & $50.0 \%$ & $35.0 \%$ \\
& $(0 \% / 2)$ & $(100 \% / 2)$ & $(100 \% / 2)$ & $(100 \% / 2)$
\end{tabular}

Entries are the percentages of each party's MPs voting in favour of each respective motion (with the percentage of each party's MPs voting in favour/total $n$ in the BRS sample in parentheses). 
Table 2 Determinants of Support for Each Division

\begin{tabular}{lllll}
\hline & \multicolumn{4}{c}{ Division } \\
\cline { 2 - 5 } & Appointment & $100 \%$ Elected $80 \%$ Elected & $60 \%$ Elected \\
\hline Bivariate Models & & & & \\
Support for Reform & 0.06 & -0.02 & -0.05 & 0.06 \\
& $(0.08)$ & $(0.08)$ & $(0.08)$ & $(0.08)$ \\
Constant & -0.43 & -0.02 & 0.15 & -0.41 \\
& $(0.27)$ & $(0.27)$ & $(0.26)$ & $(0.26)$ \\
\% Correctly Predicted & 56 & 52 & 52 & 56 \\
Observations & 253 & 247 & 252 & 255 \\
& & & & \\
Models with Controls & -0.04 & -0.03 & 0.06 & 0.18 \\
Support for Reform & $(0.16)$ & $(0.16)$ & $(0.16)$ & $(0.17)$ \\
& -0.68 & $0.89+$ & $1.20^{*}$ & $1.16^{*}$ \\
First-term MPs & $(0.51)$ & $(0.47)$ & $(0.51)$ & $(0.49)$ \\
& $7.39^{*}$ & $-4.35^{*}$ & $-5.78^{*}$ & $-6.10^{*}$ \\
Labour MPs & $(3.10)$ & $(2.08)$ & $(2.61)$ & $(2.54)$ \\
& $-0.04+$ & $0.04^{*}$ & $0.07^{*}$ & $0.07^{*}$ \\
\% Liberal Democrat & $(0.02)$ & $(0.02)$ & $(0.02)$ & $(0.02)$ \\
Vote & $0.13^{*}$ & -0.07 & $-0.10+$ & $-0.10+$ \\
\% Conservative & $(0.07)$ & $(0.05)$ & $(0.06)$ & $(0.05)$ \\
Vote & $-0.17 *$ & $0.12^{*}$ & $0.15^{*}$ & $0.16^{*}$ \\
\% Conservative $\times$ & $(0.07)$ & $(0.05)$ & $(0.06)$ & $(0.06)$ \\
Labour MPs & $-5.73+$ & 2.39 & 3.08 & 2.63 \\
Constant & $(3.20)$ & $(2.30)$ & $(2.71)$ & $(2.65)$ \\
& 62 & 62 & 65 & 68 \\
\% Correctly Predicted & 253 & 247 & 252 & 255 \\
Observations & & & & \\
\hline + p $<0.10,{ }^{*} p<0.05$, two-tailed tests. Entries are logistic regression coefficients with standard errors in \\
parentheses.
\end{tabular}


Figure 1 The Impact of Liberal Democrat Vote Shares

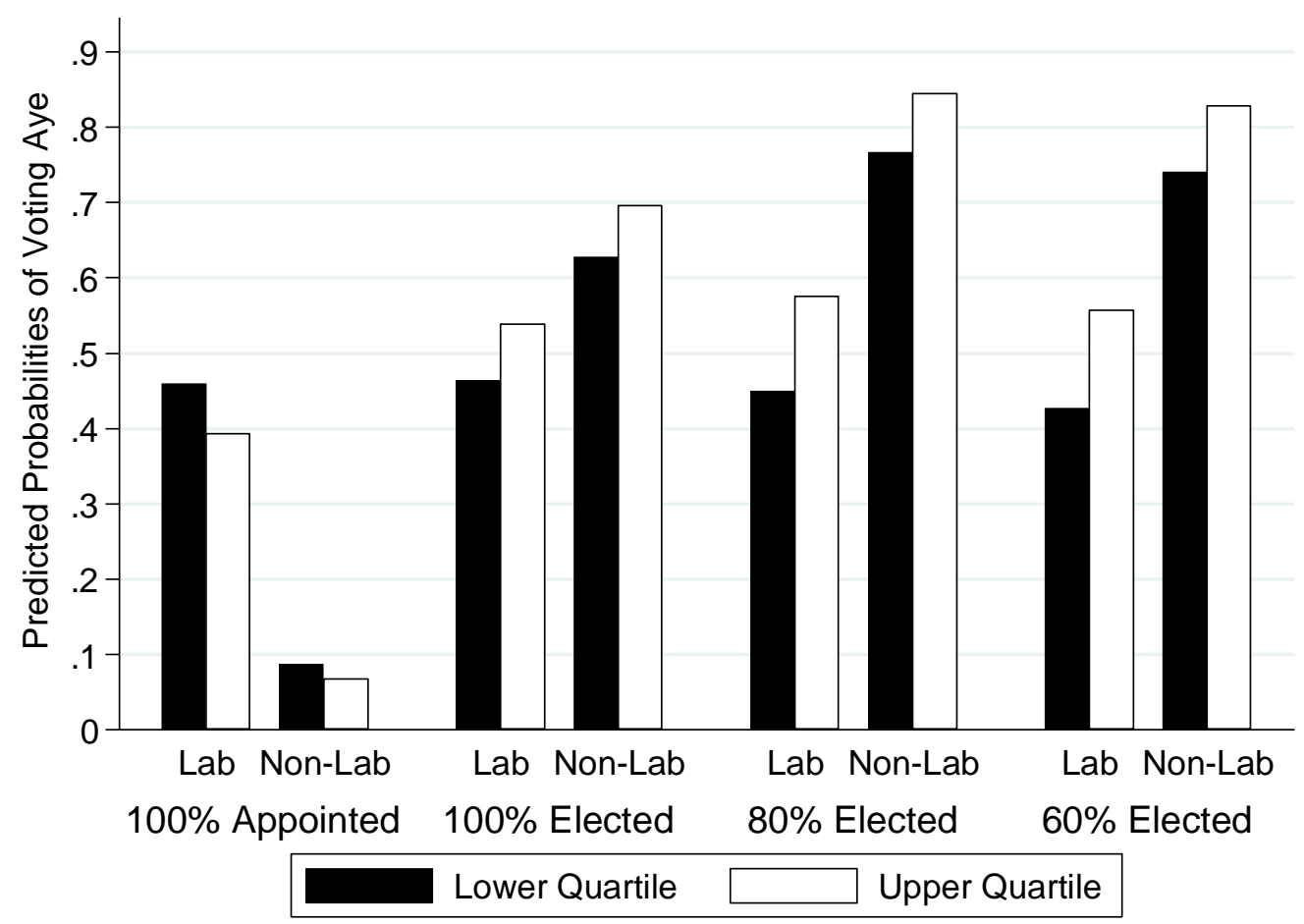

Entries are the predicted probabilities of voting in favour of each division associated with changes in the Liberal Democrat vote share variable at the lower and upper quartiles of each variable for Labour and non-Labour MPs. Predicted probabilities simulate the likelihood of voting in favour of each measure holding all other variables at their median values. 
Figure 2 The Impact of Conservative Vote Shares

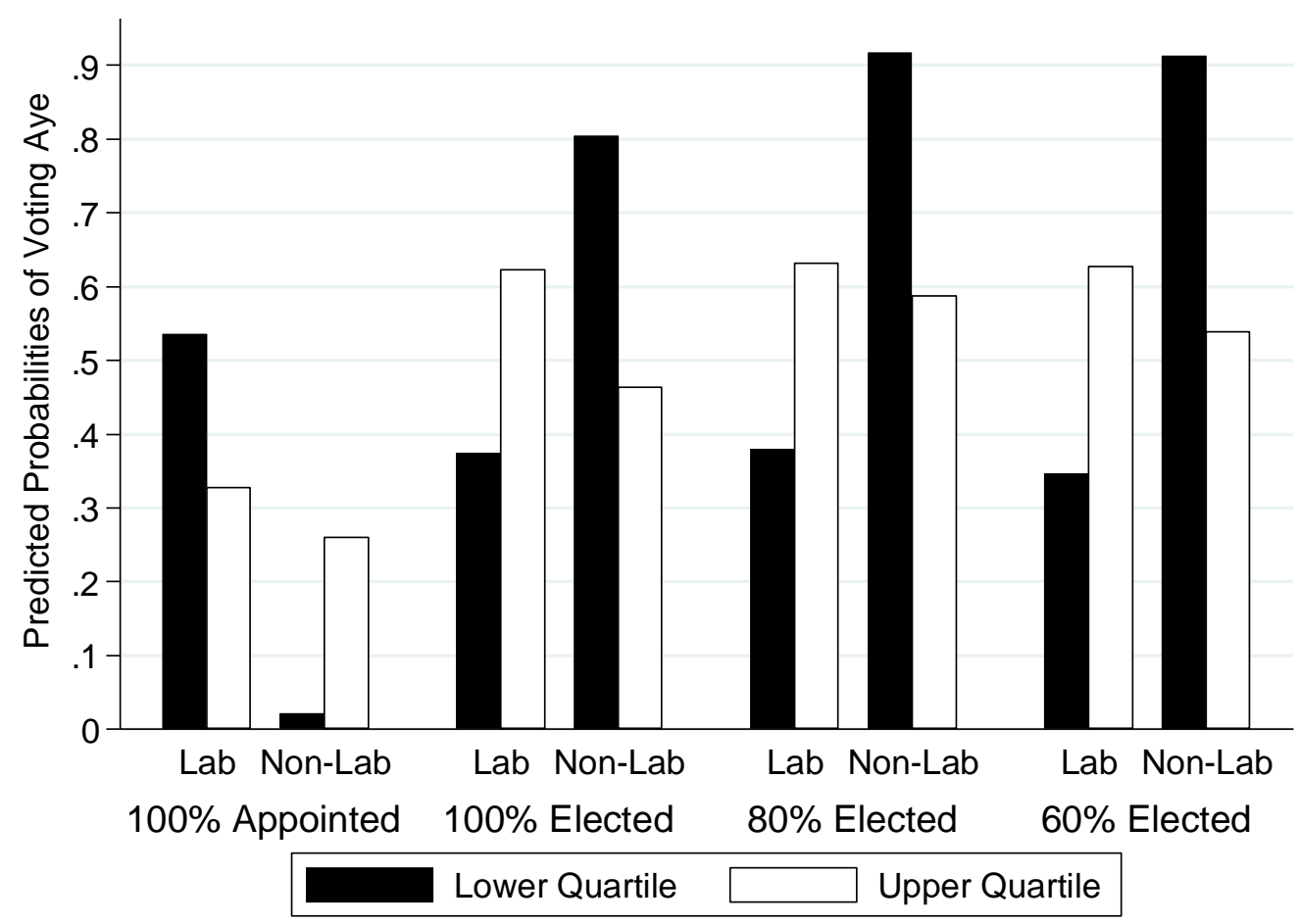

Entries are the predicted probabilities of voting in favour of each division associated with changes in the Conservative vote share variable at the lower and upper quartiles of each variable for Labour and non-Labour MPs. Predicted probabilities simulate the likelihood of voting in favour of each measure holding all other variables at their median values. 
Figure 3 Predicted Changes in Probabilities Due to Labour Party Affiliation

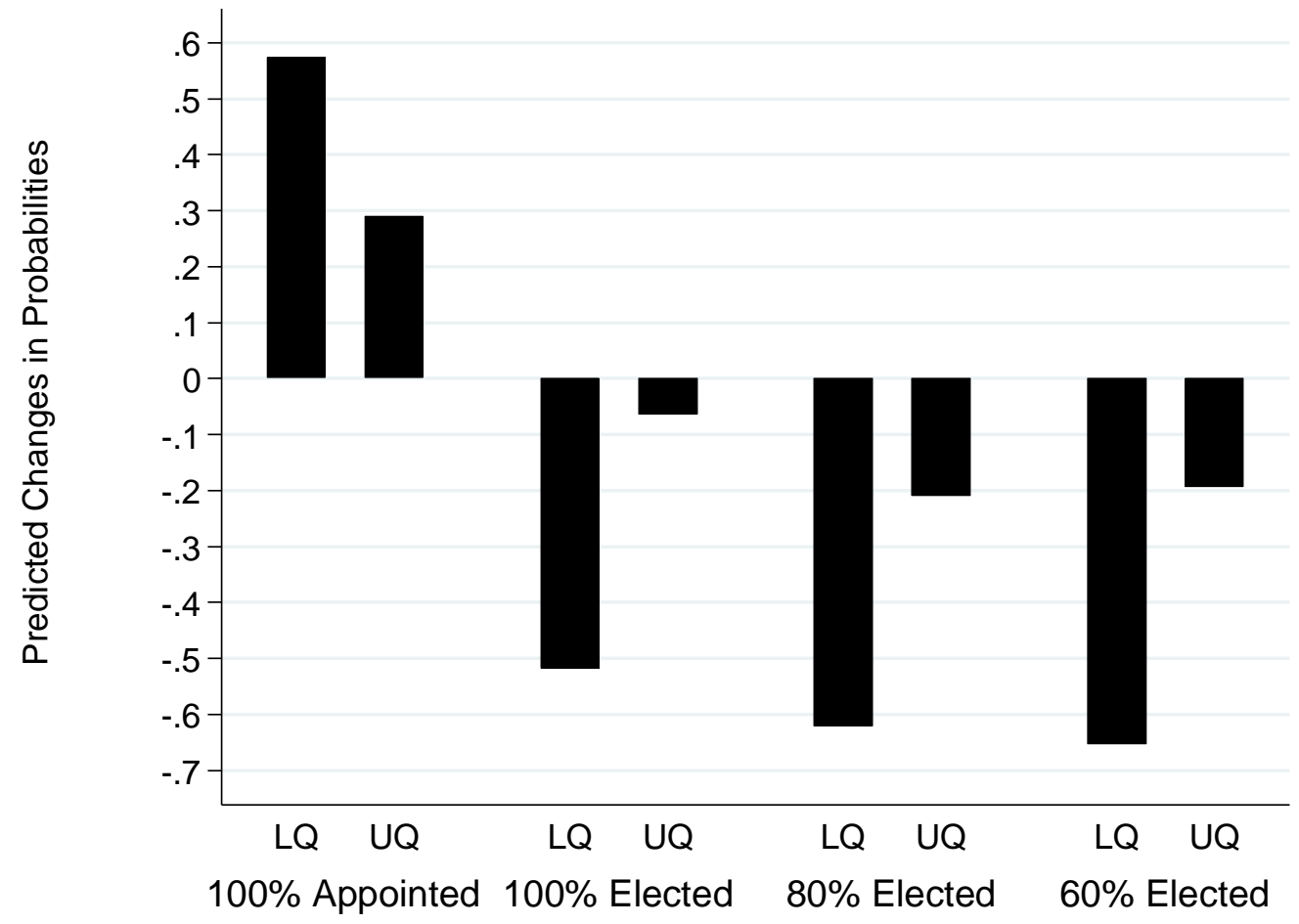

Entries are predicted changes in probability of voting in favour of each provision due to the variable measuring Labour versus all other MPs at different levels of the \% Conservative vote variable. Conservative vote shares are held to the Labour MP-specific lower (LQ) and upper (UQ) quartiles; all other variables held to their median values. 